\title{
KONTAK BAHASA ANTARA \\ KOMUNITAS TUTUR BAHASA BALI \\ DAN KOMUNITAS TUTUR BAHASA SAMAWA \\ DI KABUPATEN SUMBAWA DAN KABUPATEN SUMBAWA \\ BARAT
}

Siti Raudloh*)

\begin{abstract}
Abstrak
Kontak bahasa antara komunitas tutur bahasa Bali dan komunitas tutur bahasa Samawa di lokasi-lokasi yang dijadikan sampel berakibat pada terjadinya adaptasi linguistik yang bersifat dua arah. Artinya adaptasi itu terjadi pada kedua komunitas yang berkontak. Adaptasi linguistik tersebut tampak pada system fonologi dan leksikon.

Kategori adaptasi linguistik oleh bahasa Samawa terhadap bahasa Bali pada enklave Uma Sima dan enklave Rhee masih sedang. sedangkan di enklave Kokarlian berkategori kurang. Adapaun, adaptasi linguistik oleh bahasa Bali terhadap bahasa Sumbawa pada enklave Uma Sima dan enklave Kokarlian masuk dalam kategori sedang dan kategori kurang pada enklave Rhee.

Sementara itu, kecendrungan adapatsi linguistik yang dipengaruhi oleh segmentasi social tua dan muda menunjukkan segmen mayarakat muda lebih dominan melakukan adaptasi.

Tingkat dominasi suatu enklave dalam melakukan adaptasi linguistik ditentukan oleh beberapa faktor, di antaranya faktor geografis, sosial ekonomi, sikap bahasa, usia, dan faktor lamanya waktu tinggal.
\end{abstract}

Kata kunci: kontak bahasa, adaptasi linguistik, serapan, dan alih kode

\section{Pengantar}

Masyarakat pulau Sumbawa merupakan masyarakat majemuk. Kemajemukan itu salah satunya ditandai oleh keragaman etnis yang menghuni pulau terbesar di Provinsi Nusa Tenggara Barat ini. Etnisetnis ini tampak dari bahasa-bahasa yang mereka gunakan khususnya ketika berinteraksi secara internal. Secara kuantitas, terdapat dua etnis

\footnotetext{
*) Sarjana Pendidikan, Pembantu Pimpinan pada Kantor Bahasa Prov. NTB
} 
besar yang menghuni Pulau Sumbawa, yaitu etnis Sumbawa dengan bahasa Sumbawa di sebelah barat dan etnis Bima dengan bahasa Bima di sebelah timur. Kedua etnis ini merupakan pendudu asli Pulau Sumbawa. Di samping itu, pulau terbesar di provinsi NTB ini juga dihuni oleh etnis pendatang yang jumlahnya beragam. Di antara etnis pendatang yang sudah cukup lama menghuni Pulau Sumbawa adalah etnis Sasak, Bali, Jawa, Bugis, Bajo, Madura, dan Selayar. Etnis-etnis ini datang ke Pulau Sumbawa dengan berbagai keperluan dan alasan; ada yang datang karena faktor politis, transmigrasi, keluarga, ekonomi, atau profesi.

Dari segi distribusi geografi, etnis pendatang itu menyebar merata mulai dari ujung barat hingga timur. Etnis-etnis pendatang tersebut hidup berdampingan, baik dengan etnis asli maupun dengan etnis pendatang yang lain. Secara teoritis, dua atau lebih etnis yang berbeda bahasa hidup berdampingan dalam satu wilayah geografis pasti akan menimbulkan fenomena adaptasi baik adaptasi social maupun adapatasi linguistik. Mahsun (2006: 1) menyatakan bahwa adaptasi sosial yang terjadi akibat kontak dua atau lebih komunitas yang berbeda bahasa dapat dilihat dari adaptasi linguistik; tingginya adaptasi linguistik menandakan tingginya pula adaptasi sosial dan begitu juga sebaliknya. Adptasi linguistik yang dimaksud adalah adanya bentuk-bentuk lingual yang berkembang pada salah satu pihak atau semua pihak yang merupakan bentuk yang dipengaruhi oleh bentuk lingual pihak lain. Bentuk-bentuk adaptasi linguistik itu dapat berupa penyesuaian, yaitu penggantian, penambahan, pencampuran, ataupun pelesapan. Sejalan dengan hal tersebut Mackey (dalam Rahardi,2001:17) mengatakan bahwa kontak bahasa memunculkan peristiwa saling memengaruhi antara bahasa yang satu dengan yang lain. 
Berkaitan dengan hal tersebut, penutur bahasa bahasa Bali (etnis Bali) yang notabena merupakan etnis minoritas yang dituntut untuk sedikit-banyak melakukan adaptasi lingual dengan mampu berkomunikasi menggunakan bahasa etnis asli yang mayoritas, yaitu bahasa Samawa.

Kondisi masyarakat yang di dalamnya terjadi kontak bahasa dapat membawa akibat adanya hubungan saling ketergantungan antara bahasa yang satu dengan bahasa yang lain. Artinya tidak akan pernah mungkin seorang penutur dalam masyarakat tutur yang demikian hanya akan menggunakan satu bahasa secara murni.

Untuk melihat dan membuktikan sejauh mana adaptasi linguistik yang terjadi pada kontak bahasa antara komunitas tutur bahasa Bali dan komunitas tutur bahasa Samawa dilakukkanlah penelitian ini. Dengan demikian, masalah utama yang akan dikaji adalah masalah tingkat prosentasi adaptasi linguistik berikut faktor pendukung dan faktor yang tidak mendukung. Di samping itu, akan dilihat juga pengaruh segmentasi sosial khususnya usia tua dan muda dalam tingkat persentase adaptasi linguistik tersebut.

Metode penelitian ini menggunakan pendekatan sosiolinguistik, dialektologi diakronis, dan linguistik historis komparatif yang meliputi metode kuantitatif berupa perhitungan dengan cara mengolah data kualitatif menjadi kuantitatif. Untuk analisis data dengan tujuan memperoleh gambaran ihwal wujud adaptasi linguistik akan dengan menggunakan metode padan: teknik hubung-banding menyamakan (HBS) dan teknik hubung-banding membedakan (HBB). 


\section{Pembahasan}

\subsection{Pengaruh Bahasa Samawa terhadap Bahasa Bali}

\subsubsection{Pengaruh Bahasa Samawa terhadap Bahasa Bali Uma}

\section{Sima}

Adaptasi linguistik yang dilakukan komunitas tutur bahasa Bali (BB) terhadap bahasa Samawa di Kelurahan Uma Sima ditemukan dalam dua bentuk, yaitu serapan fonologi dan serapan leksikon. Serapan fonologi, misalnya pada kata $s \beth \eta k \beth q$. Bentuk ini dalam BB direalisasikan dengan bentuk $s \beth \eta k \beth$ atau capil, tampa fonem /q/ pada posisi akhir. Dengan demikian, BB menyerap unsur fonologi berupa fonem /q/ pada posisi akhir.

Sementara itu, serapan leksikon yang dilakukan oleh BB tampak pada bentuk molak 'rakus', takit 'takut', pukil 'pukul', dan mampis 'harum'. Bentuk-bentuk ini diserap oleh penutur bahasa Bali sengmen muda secara utuh dari bahasa sumbawa, karena dalam BB bentuk-bentuk

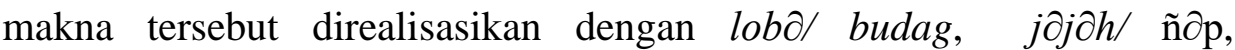

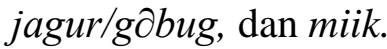

\subsubsection{Pengaruh Bahasa Samawa terhadap Bahasa Bali-Rhee}

Adaptasi linguistik yang dilakukan komunitas tutur BB terhadap bahasa Samawa di Desa Rhee ditemukan hanya dalam bentuk serapan leksikon saja yang berjumlah 11 kata. Dari 11 kata serapan tersebut terdapat 7 kata yang merupakan serapan yang dilakukan segmen sosial muda dan 4 kata yang dilakukan segmen sosial tua. Serapan yang terjadi pada segmen sosial muda dan tua ini kesemuanya menyerupai bentuk dari bahasa Sumbawa Standar karena wilayah Rhee termasuk dalam wilayah pakai dialek Sumbawa Besar yang dijadikan standar bahasa

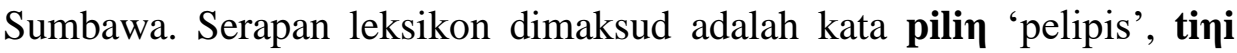




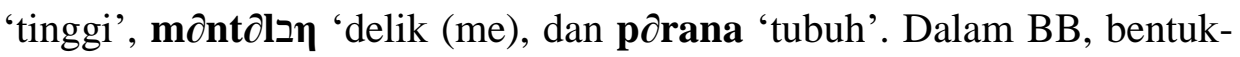

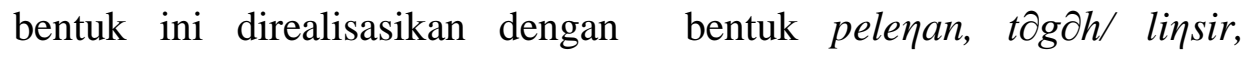
$m \partial l \partial r / n \partial r \partial \eta$, dan $a w a k$.

\subsubsection{Pengaruh Bahasa Samawa terhadap Bahasa Bali- Kokarlian}

Adaptasi linguistik yang dilakukan komunitas tutur bahasa Bali terhadap bahasa Samawa di dusun Kokarlian ditemukan hanya dalam bentuk serapan leksikon saja berjumlah 7 kata. Dari 7 kata serapan terdapat 4 kata yang merupakan unsur serapan yang dilakukan segmen sosial muda, 2 kata dilakukan oleh segmen sosial tua, dan 1 kata dilakukan segmen sosial tua dan muda. Adaptasi linguistik yang berupa leksikon ini, 5 kata di antaranya menyerupai bentuk dari bahasa Samawa Standar dan 2 kata serapan lainya berasal dari bahasa Samawa varian setempat. Serapan leksikon dimaksud adalah kata $\mathbf{g} \partial \mathbf{d}$ ב 'bodoh', sisin 'cincin', dan jangut 'dagu'. Bentuk-benuk ini diserap oleh penutur bahasa Bali muda secara utuh, karena dalam BB, bentuk-bentuk

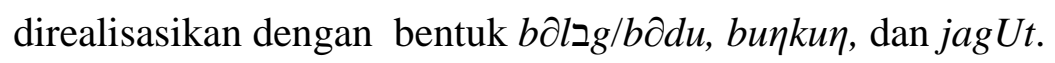

\subsubsection{Pengaruh Bahasa Samawa yang Berbentuk Alih Kode}

Adaptasi linguistik yang berwujud alih kode pada semua enklave komunitas tutur bahasa Bali berlangsung satu arah, yaitu komunitas tutur bahasa Bali-lah yang cenderung melakukan adaptasi dalam wujud alih kode ketika berkomunikasi dengan komunitas tutur bahasa Samawa. Namun data alih kode yang dijumpai bukan dalam bentuk data kebahasaan atau rekaman peristiwa tutur, tetapi dijumpai dalam bentuk informasi dari informan. Informasi itu berupa kasus tentang dua orang penutur bahasa Bali yang sedang berkomunkasi menggunakan bahasa Bali didatangi oleh penutur komunitas Samawa, bahasa pengantar dalam komunikasi berubah menjadi bahasa Samawa secara utuh apabila bentuk 
tuturan itu mereka kuasai semuanya dan kadang-kadang mencampurnya dengan bahasa Indonesia jika lawan bicaranya lebih tua dan sudah saling kenal. Akan tetapi, apabila dengan anak muda atau belum dikenal biasanya menggunakan bahasa Indonesia.

Menurut mereka, hal ini disebabkan komunitas Sumbawa selain kurang memahami dan mengerti bahasa komunitas Bali, juga disebabkan kesadaran mereka sebagai etnis pendatang sehingga dituntut untuk mempelajari bahasa setempat. Selain itu, tuntutan mempelajari bahasa Samawa juga dimaksudkan agar mereka memiliki wawasan yang luas untuk menjalin komunikasi dan interaksi dengan komunitas Sumbawa secara umum. Dengan begitu, akan terjalin suasana komunikasi dan hubungan yang baik antara mereka dengan komunitas Sumbawa.

\subsection{Pengaruh Bahasa Bali terhadap Bahasa Samawa}

\subsubsection{Pengaruh Bahasa Bali terhadap Bahasa Samawa-Uma Sima}

Berdasarkan data yang diperoleh dari keseluruhan sampel penelaahan yang berlokasi di kelurahan Uma Sima, diperoleh gambaran bahwa adaptasi linguistik yang dilakukan komunitas tutur bahasa Samawa terhadap bahasa Bali hanya ditemukan dalam bentuk serapan fonologi, serapan leksikon, dan baster. Serapan fonologi, misalnya kata nutah 'muntah' penutur bahasa Samawa-Uma Sima tua dan muda mengadopsi fonem /h/ pada posisi akhir dari penutur bahasa Bali, karena dalam bahasa Samawa standar makna tersebut direalisasikan dengan nutaq. Kaidah perubahan bunyi yang diturunkan dari PBSS *q/-\# > h, bukanlah perubahan bunyi konsonan yang berlaku pada bahasa Samawa, melainkan perubahan bunyi tersebut berlaku pada bahasa Bali, misalnya: PBSS * mataq bahasa Bali menjadi matah dan dalam bahasa Samawa 
menjadi mataq. Dengan demikian bentuk qutah adalah bentuk yang dipinjam penutur bahasa Samawa-Uma Sima dari bahasa Bali, namun perubahan bunyi konsonan ini terjadi secara tidak teratur, artinya perubahan itu tidak dapat digeneralisasikan karena tidak didukung data lain yang sejenis.

Adaptasi linguistik yang berupa serapan leksikon dalam bahasa Samawa dari bahasa Bali, misalnya kata bənen 'gigi dan suwun 'junjung' bentuk ini diserap oleh penutur bahasa Sumbawa tua dari bahasa Bali varian setempat, karena dalam bahasa Sumbawa makna tersebut masing-masing direalisasikan dengan bentuk isit ju iik dan

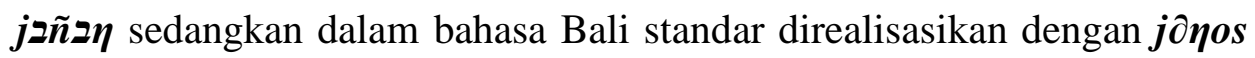

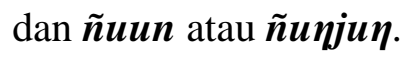

Bentuk baster adalah bentuk campuran antara unsur bahasa asli (Samawa) dengan unsur dalam bahasa lain (Bali). Dari data yang terkumpul ditemukan hanya satu data bentuk baster berupa frase yang

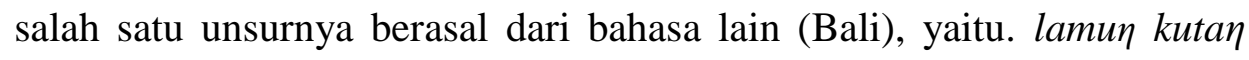
'singlet' bentuk ini ditemukan pada penutur Samawa-Uma Sima muda. Kata lamu $\eta$ pada konstruksi frase tersebut adalah kata asli bahasa

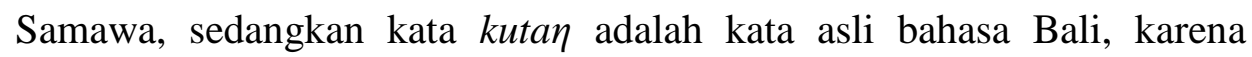
dalam bahasa Samawa standar makna tersebut direalisasikan dengan

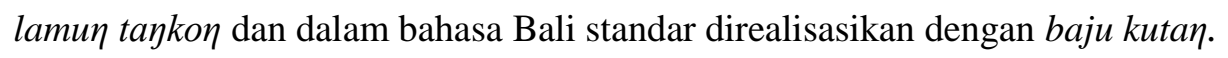

\subsubsection{Pengaruh Bahasa Bali terhadap Bahasa Samawa-Rhee}

Adaptasi linguistik yang dilakukan komunitas tutur bahasa Samawa terhadap bahasa Bali di Desa Rhee hanya ditemukan dalam bentuk serapan fonologi dan baster. Serapan fonologi, misalnya Komunitas tutur bahasa Samawa-Rhee tua dan muda mengadopsi fonem /h/ dari bahasa Bali, yaitu pada kata sugi $>$ sugih 'kaya'. Penutur bahasa 
Samawa melakukan inovasi internal, karena dalam bahasa Samawa tidak mengenal fonem $/ \mathrm{h} /$ pada posisi akhir. Sementara itu adaptasi linguistik dalam bentuk serapan baster sebagaimana yang ditemukan di enclave Uma Sima.

\subsubsection{Pengaruh Bahasa Bali terhadap Bahasa Sumbawa- Kokarlian}

Berdasarkan data yang diperoleh dari keseluruhan sampel penelaahan yang berlokasi di Dusun Kokarlian, diperoleh gambaran bahwa adaptasi linguistik yang dilakukan komunitas tutur bahasa Samawa terhadap bahasa Bali hanya ditemukan dalam bentuk serapan fonologi dan leksikon.

Adaptasi linguistik yang berwujud serapan fonologi, misalnya kata buto 'buta', penutur bahasa Samawa-Kokarlian tua dan muda mengadopsi vokal akhir / $\partial /$ dari penutur bahasa Bali, karena dalam bahasa Samawa makna tersebut direalisasikan dengan bentuk buta.

Sementara itu, adaptasi linguistik yang berupa serapan leksikon, misalnya kata gedap 'raba' dan ñilap 'jilat'. Bentuk tersebut diserap oleh penutur bahasa Sumbawa muda dari bahasa Bali, karena dalam bahasa Sumbawa seharusnya makna tersebut masing-masing direalisasikan dengan bentuk olas dan lela.

\subsection{Kecenderungan Masing-Masing Enklave Yang Melakukan Adaptasi Linguistik}

Kecenderungan dari adaptasi linguistik yang terkait dengan kuatkurangnya pengaruh bahasa Samawa terhadap bahasa Bali pada enklave Uma Sima dan enklave Rhee berkategori sedang, yaitu sebesar 42,42\% dan 33,33\%. Sementara itu, enklave Kokarlian berkategori kurang, yaitu 
sebesar 24,24\%. Sedangkan pengaruh bahasa Bali terhadap bahasa Samawa pada enklave Uma Sima dan enklave Kokarlian termasuk dalam kreteria sedang, yaitu sebesar 34,5\% dan 41,38\%. Sementara itu, enklave Rhee termasuk dalam kreteria kurang, yaitu sebesar $24,14 \%$.

\subsection{Kecenderungan Segmen Tua-Muda dalam Melakukan Adaptasi Linguistik pada Komunitas Tutur Bahasa Bali}

Kecenderungan dari adaptasi linguistik yang terkait dengan kuatkurangnya pengaruh-memengaruhi antara bahasa Samawa dan bahasa Bali dari segmen tua maupun segmen muda menunjukkan segmen sosial muda pada semua enklave masuk dalam kreteria dominan, baik pengaruh dari bahasa Samawa maupun pengaruh dari bahasa Indonesia, sedangkan segmen sosial tua pada enklave Uma Sima termasuk dalam kreteria kurang dominan. Adapun enklave Rhee dan enklave Kokarlian termasuk dalam kreteria sedang, baik pengaruh dari bahasa Samawa maupun pengaruh dari bahasa Indoesia.

\subsection{Kecenderungan Segmen Tua-Muda dalam Melakukan Adaptasi Linguistik pada Komunitas Tutur Bahasa Samawa}

Seperti halnya bahasa Bali, Kecenderungan pengaruh bahasa Bali dan bahasa Indonesia terhadap bahasa Samawa menunjukkan segmen sosial muda pada semua enklave masuk dalam kreteria dominan, segmen sosial tua pada enklave Uma Sima masuk dalam kreteria dominan, sedangkan enklave Rhee dan enkave Kokarlian termasuk dalam kreteria sedang, dan kecenderungan pengaruh bahasa Indonesia terhadap bahasa Samawa segmen sosial tua pada semua enklave termasuk dalam kreteria sedang. 


\subsection{Faktor-Faktor yang Memengaruhi Kecenderungan Suatu Segmen Melakukan Adaptasi Linguistik}

Tingkat dominasi suatu enklave dalam melakukan adaptasi linguistik disebabkan oleh beberapa faktor, yaitu:

\section{Faktor geografis}

Letak geografis suatu wilayah yang strategis disertai pula dengan tingkat kelancaran sarana transportasi untuk mencapai wilayah tersebut setidaknya akan berpengaruh juga pada bahasa yang digunakan untuk berkomunikasi. Suatu daerah yang terbuka akan lebih banyak mendapat pengaruh dari bahasa lain. Enklave Uma Sima yang terletak di ibukota kabupaten merupakan daerah yang sangat strategis dan terbuka. Dilihat dari segi ini seharusnya enclave Uma Sima masuk kategori dominan. Akan tetapi data menunjukkan enclave ini berkategori sedang bersama dengan enklave Rhee yang secara geografis kurang strategis,, walaupun persentasenya berbeda. Hal ini disebabkan komunitas BaliRhee memiliki tingkat mobilitas yang cukup tinggi. Menurut para informan komunitas Bali-Rhee sering melakukan kontak dengan komunitas Sumbawa di pusat kota (Alas) untuk menjual hasil pertanian. Selain itu, komunitas tutur bahasa Bali-Rhee banyak yang menyekolahkan anak-anaknya di Kecamatan Alas dan Kecamatan Utan yang kemudian membuka peluang terjadinya kontak yang lebih intensif baik secara kualitas maupun kuantitas.

Adapaun adaptasi linguistik oleh enklave Bali-Kokarlian yang terletak jauh dari pusat pemerintahan berkategori kurang.

\section{Faktor sosial}

Faktor sosial meliputi dua hal yaitu: (a) mata pencaharian, Mata pencaharian penduduk di enklave Uma Sima lebih bervariatif dibandingkan dengan mata pencaharian penduduk di enklave Kokarlian. 
Mayoritas penduduk di enklave Kokarlian adalah petani dan hanya sebagian kecil yang berprofesi sebagai pegawai dan pedagang. Pada umumnya petani tidak memiliki mobilitas untuk bepergian yang tinggi. Dari data hasil wawancara rata-rata mereka bepergian ke luar wilayah hanya berkisar 2 sampai 3 kali dalam setahun. Alasan kepergian mereka hanya untuk memenuhi kebutuhan untuk pertanian dan mengunjungi keluarga. Dibandingkan dengan penduduk enklave Uma Sima yang mata pencahariannya lebih variatif dan didukung pula oleh mobilitas penduduk yang tinggi maka enklave ini melakukan adaptasi linguistik lebih tinggi dibandingkan dengan enklave Kokarlian. Mudahnya transportasi dan tingkat kebutuhan kerja memungkinkan untuk sering bepergian. Komposisi mata pencaharian penduduk, seperti pegawai, pedagang, dan wiraswasta merupakan mata pencaharian yang memiliki mobiltas dan tingkat interaksi yang tinggi. Berbeda dengan enklave Rhee, meskipun mayoritas penduduknya petani, akan tetepi mobilitas penduduknya cukup tinggi sebagaimana yang telah dijelaskan di atas. (b) Kebutuhan ( feltneed motive), dari hasil wawancara, alasan utama penduduk enklave Bali mempelajari bahasa Samawa disebabkan karena komunitas Bali adalah pendatang yang datang ke Sumbawa untuk mencari lapangan pekerjaan sehingga harus mempelajari bahasa setempat. Selain itu juga dimaksudkan agar mereka memiliki wawasan yang luas untuk menjalin komunikasi dan interaksi dengan komunitas Sumbawa secara umum. Dengan begitu, akan terjalin suasana komunikasi dan hubungan yang baik antara mereka dengan komunitas Sumbawa dan Komunitas pendatang lainnya.

\section{Faktor sikap bahasa}

Selain faktor tersebut di atas, komunitas tutur bahasa Bali yang tinggal di Sumbawa pada masing-masing enklave memandang sistem 
bahasanya sendiri dan bahasa mitra kontaknya sama-sama berprestise, sehingga mereka tetap mempertahankan keaslian bahasanya. Hal itu terbukti dengan wujud serapan yang ditemukan dilapangan pada masingmasing enklave berkategori sedang dan kurang dominan, akan tetapi mereka juga memandang bahasa mitra kontaknya berprestise dengan bukti mereka mampu beralihkode dengan bahasa Samawa.

\section{Faktor Usia}

Faktor usia sangat berpengaruh terhadap dominan-tidaknya adaptasi linguistik yang dilakukan oleh dua komunitas tutur yang saling bekontak. Hal ini dapat dibuktikan dengan hasil perhitungan di atas yang menyebutkan bahwa, adaptasi linguistik yang dilakukan oleh segmen sosial muda pada semua enklave termasuk dalam kreteria dominan, baik adaptasi linguistik dari bahasa Samawa ke bahasa Bali, dari bahasa Bali ke bahasa Samawa, maupun dari bahasa Indonesia ke bahasa Samawa dan bahasa Bali. Sedangkan adaptasi linguistik yang dilakukan oleh segmen sosial tua termasuk dalam kreteria sedang dan kurang.

Dominannya adaptasi linguistik yang dilakukan oleh sengmen sosial muda terkait dengan mobilitas mereka yang cukup tinggi. Berdasarkan hasil wawancara dilapangan menyebutkan bahwa, mereka melakukan bepergian rata-rata satu bulan sekali. Selain itu bahasa anak muda memiliki sifat yang variatif, esklusif, aggresif, dan inovatif. Kita banyak mengenal bahasa eksklusif anak muda seperti bahasa prokem dan bahasa gaul atau bahasa rahasia lainnya yang tidak difahami oleh orang lain atau kelompok lain. Dalam kata lain bahasa anak muda merupakan bahasa yang dinamis. Ia berkembang setiap saat sesuai dengan perkembangan lingkungan dan kebutuhan kelompok mereka. Di lain pihak bahasa orang tua terbukti lebih terbuka, apresiatif, akomodatif, protektif (penuh nasehat), dan konservatif. Terbuka dalam arti tidak 
mengesklusifkan diri dengan menciptakan bahasa-bahasa khusus supaya berbeda dengan kelompok bahasa orang tua yang lain. Akomodatif dan apresiatif bermakna tidak banyak melakukan pemberontakan secara linguistik dengan melawan bentuk-bentuk baru dan menciptakan bentukbentuk tandingan. Bahasa mereka, seperti umumnya sifat mereka, lebih banyak nerimo (menerima) dan lebih arif atau bijaksana dibandingkan dengan bahasa anak muda, dan konservatif dalam makna yang statis, yaitu tidak melakukan pembaruan sesuai dengan perkembangan dan kebutuhan lingkungan mereka (Hidayat, 2007).

\section{Faktor Lamanya Waktu Tinggal}

Lamanya waktu tinggal komunitas tutur bahasa Bali di Sumbawa sedikit-banyak juga berpengaruh terhadap adaptasi linguistik yang dilakukan, sebagaimana yang dikatakan oleh Keraf (dalam Burhanudin, 2005:74) dalam keadan biasa, suatu batas politis yang baru dapat menyebabkan perbedaan linguistis dalam masa kurun waktu 50 tahun. Suatu enklave yang lebih lama tinggal akan berbeda bahasanya dengan enklave yang baru beberapa tahun tinggal. Komunitas tutur bahasa Bali enklave Uma Sima dan enklave Rhee yang telah tinggal di Sumbawa selama lebih dari 35 tahun adaptasi linguistik yang dilakukan berkategori sedang dan enklave Kokarlian dengan waktu tinggal selama 25 tahun berkategori kurang.

\section{Simpulan}

Berdasakan uraian di atas, dapat dikemukakan beberapa hal sebagai simpulan dari penelitian ini.

Secara umum kontak dua komunitas yang berbeda bahasa berakibat pada terjadinya adaptasi sosial dan linguistik bersifat dua arah 
yaitu kedua belah pihak melakukan adaptasi. Hal ini terbukti dengan kontak bahasa antara bahasa Samawa dan bahasa Bali di Kabupaten Sumbawa dan Kabupaten Sumbawa Barat, yaitu ditemukan bukti-bukti konkrit terjadinya adaptasi linguistik yang dilakukan oleh kedua belah pihak. Adaptasi linguistik yang ditemukan adalah serapan fonologi, baster, dan serapan leksikon. Adapun adaptasi yang berbentuk alih kode hanya bersifat satu arah yaitu komunitas tutur bahasa Balilah yang cenderung melakukan adaptasi dalam wujud alih kode ketika berkomunikasi dengan komunitas tutur bahasa Samawa.

Kecenderungan dari adaptasi linguistik yang terkait dengan kuatkurangnya pengaruh bahasa Samawa terhadap bahasa Bali pada enklave Uma Sima dan enklave Rhee berkategori sedang, dan enklave Kokarlian berkategori kurang. Adapun pengaruh bahasa Bali terhadap bahasa Samawa pada enklave Uma Sima dan enklave Kokarlian termasuk dalam kreteria sedang dan enklave Rhee termasuk dalam kreteria kurang.

Adaptasi linguistik yang terkait dengan kuat-kurangnya pengaruh-memengaruhi antara bahasa Samawa dan bahasa Bali dari segmen tua maupun segmen muda menunjukkan segmen sosial muda pada semua enklave termasuk dalam kreteria dominan, baik pengaruh dari bahasa Samawa maupun pengaruh dari bahasa Indonesia, sedangkan segmen sosial tua pada enklave Uma Sima termasuk dalam kreteria kurang dominan sedangkan enklave Rhee dan enklave Kokarlian termasuk dalam kreteria sedang, baik pengaruh dari bahasa Samawa maupun pengaruh dari bahasa Indoesia.

Adapun kecenderungan pengaruh bahasa Bali dan bahasa Indonesia terhadap bahasa Samawa menunjukkan segmen sosial muda pada semua enklave termasuk dalam kreteria dominan, segmen sosial tua kecenderungan pengaruh bahasa Bali terhadap bahasa Samawa pada 
enklave Uma Sima termasuk dalam kreteria dominan sedangkan enklave Rhee dan enkave Kokarlian termasuk dalam kreteria sedang, dan kecenderungan pengaruh bahasa Indonesia terhadap bahasa Samawa segmen sosial tua pada semua enklave termasuk dalam kreteria sedang.

Tingkat dominasi suatu enklave dalam melakukan adaptasi linguistik disebabkan oleh beberapa faktor, yaitu Faktor geografis, faktor sosial, faktor sikap bahasa, faktor usia, dan faktor lamanya waktu tinggal. 


\section{DAFTAR PUSTAKA}

Bloomfield, Leonard. 1995. Bahasa (Language). Jakarta: Gramedia Pustaka Utama.

Burhanuddin, et al. 2005. "Kontak Bahasa Antara Bahasa Sumbawa di Lombok Timur Dengan Bahasa Sasak". Mataram: Laporan Penelitian Kelompok Kantor Bahasa Provinsi Nusa Tenggara Barat.

Balai Penelitian Bahasa Singaraja. 1975. Kamus Indonesia-Bali. Jakarta: Pusat Pembinaan dan Pengembangan Bahasa Departemen Pendidikan dan Kebudayaan.

Chaer, Abdul dan Leonie Agustina. 1995. Sosiolinguistik: Suatu Pengantar. Jakarta: Rineka Cipta.

Mahsun. 1995. Dialektologi Diakronis: Sebuah Pengantar. Yogyakarta: Gadjah Mada University Prees.

Mahsun. 2005. Metode Penelitian Bahasa:Tahapan Strategi, Metode, dan Tekniknya. Jakarta: PT Raja Grafindo Persada.

Mahsun. 2006. Bahasa dan Relasi Sosial: Telaah Kesepadanan Adaptasi Linguistik dengan Adaptasi Sosial. Yogyakarta: Gama Media.

Rahardi, Kunjana. 2001. Sosiolinguistik, Kode dan Alih Kode.Yogyakarta: Pustaka Pelajar.

Hidayat, Toni Samsul. 2007 Kontak Bahasa Antara Komunitas Tutur Bahasa Sasak dan Komunitas Tutur Bahasa Sumbawa di Sumbawa Barat dan Sumbawa

Yogyakarta: Gama Media 